\title{
Paradigm shift from New Public Administration to New Public Management: theory and practice in Africa
}

\author{
S VYAS-DOORGAPERSAD ${ }^{1}$
}

\begin{abstract}
The African continent is facing a number of administrative crises. The recent decline of public administration on the continent has forced some African countries to re-assess their governance systems. Their public service reforms are evidence of the emergence of New Public Management (NPM) for improved public sector administrative structures and operations. This article discusses the paradigm shifts from New Public Administration to New Public Management, as a means of meeting public administration challenges in Africa. At a contextual level, the paper examines the practical implementation by some African countries of NPM and the outcomes of NPM-led reform in these countries.
\end{abstract}

Key words: Public Administration (PA); New Public Administration (NPA); New Public Management (NPM); Public Value Management (PVM); paradigm; paradigm shift; public service reforms; governance.

Disciplines: Public Management, Political Science, Sociology, Economics.

\section{Introduction}

The progression from New Public Administration to New Public Management has stimulated intellectual debate amongst scholars, raising certain probing questions. Should New Public Management (NPM) be regarded as a new paradigm? How does NPM differ from Public Administration (PA)? Do NPM and PA offer different approaches or do they complement each other? It can further be argued that "the existence of competing paradigms in public administration strengthens, instead of erodes, the future of the field. Theoretical breakthroughs (reconstruction of new theories) may come more readily when competitive approaches are allowed to coexist" (Lan and Anders 2000: 162). A paradigm is:

a framework used in thinking about and organizing an understanding of natural or social phenomena. All societies, and the individuals within them, tend to have relatively

1. Prof. Shikha Vyas-Doorgapersad is a member of the subject group Public Management and Administration, School of Basic Sciences, Vaal Triangle Campus, North-West University. Email: Shikha.VyasDoorgapersad@nwu.ac.za 
fixed assumptions about how to understand and interpret the world, but there is great variation in these assumptions from place to place and from time to time ... [.] As sets of assumptions change over time this process can be referred to as a paradigmatic shift: there emerges a new way of looking at the world (Online Dictionary of the Social Sciences 2006: 1).

The notion of a paradigm in the social sciences was introduced by Thomas Kuhn in his classic work entitled Structure of Scientific Revolutions (1970) that raised scholarly debate in intellectual circles. The understanding of Kuhn's paradigms can assist scholars to discuss the paradigms of Public Administration. This article therefore builds on the theoretical/philosophical aspects of PA and NPM, whereby it can be debated that

it does not matter whether or not NPM is a paradigm. For one thing, its use as a rhetorical device gives it stronger intellectual credentials ... rather than being opposite paradigms, one of which must defeat the other, they appear to represent incommensurable ways of looking at their subject, each having its contribution to make (Gow and Dufour 2000: 590).

Through this theoretical understanding, the paper aims to explore the implementation and practise of NPM as a new paradigm (hypothetical) and the outcomes of NPM-led reforms introduced on the African continent.

\section{Paradigms of Public Administration}

In his article on public administration, Henry (1975) traced the evolution of the field by identifying a number of paradigms that he organized around three themes: focus, or what to study; locus, or where to find it; and the place of values. Others thought that organisation theories lend themselves to analysis as paradigms, but rather in the incommensurable sense of Burrell and Morgan. For others still, paradigm and models are roughly equivalent (quoted by Chevallier and Loschak 1978: 90; Frederickson 1980: 16; Gow and Dufour 2000: 577).

Debating on the existence of paradigms, Starling (Botes 1988: 121) stated that the problem with the view that

\section{Public Administration can and should have a paradigm and thus take its place among the other science is ... two fold ..., first, it will direct the efforts of scholars away from the resolution of pressing administrative problems to the study of arcane theoretical puzzles. Second, the paradigm dictates the connective taxonomies of important subjects of inquiry and forces the scholars, so to speak, to work and to think within the ambits of paradigms.}

Various schools of thought have emerged to discuss the relevance of paradigms in Public Administration. According to the classical empiricist (objective/ positivist) school of thought, "to determine whether Public Administration does have paradigmatic status, it must be determined whether universally accepted theories about Public Administration exist" (Freysen 1988: 162-163). In terms of the empiricist school of thought, it would appear that "Public Administration is not in a position to claim paradigmatic status in an objective sense" (Freysen 1988: 163). Regarding the existence of paradigms in Public Administration in a subjective sense, it can be commented that "the generic approach is universally accepted" (Freysen 1988: 163). If the resemblance, correlation and relationship between 
"POSDCORB, POLC, and PAFHRIER" (Freysen 1988: 163) are emphasised and a synthesis is brought about, Cloete's generic view (Freysen 1988: 163) or rational analytical model (Freysen 1988: 163) can constitute a paradigm, because it is intuitively logical (Freysen 1988: 163). Cloete propagated that Public Administration comprises six generic administrative processes or functions, namely: policymaking, organising, financing, personnel provision and utilisation, determination of work procedures and control. These generic administrative processes or functions became the centrepiece of the subject matter and the focus of Public Administration education (Maserumule and Mashigo 2011: 6).

If paradigmatic status in an objective, monistic sense is more than a philosophical ideology, it would seem to be unattainable in the social sciences and therefore in Public Administration. If, on the other hand, paradigmatic status is conceived of in a pluralistic, subjective sense and conforms to the basic characteristics of social science, 'paradigmatic' status seems to be attainable (Freysen 1988: 164).

Either in support for or in opposition to this debate, scholars (Kuhn 1970; Henry 1975; Chevallier and Loschak 1978; Frederickson 1980; Minogue 1983; Botes 1988; Freysen 1988; Wilding 1992; Peters and Savoie 1995; Thomas 1996; Charih and Rouillard 1997; Cheung 1997; Massey 1997; Kaboolian 1998; Terry 1998) have profoundly studied and analysed the relevance of paradigms in Public Administration. In a book entitled Action Theory for Pubic Administration, Michael M. Harmons (1981: 1-194) stated:

the propositions of Public Administration constitute an outline for an Action Theory
paradigm for Public Administration. The integration of its assumptive, explanatory,
and normative elements satisfies the criteria of paradigm status ... [.] It provides a
framerwork within which 'applied' theory and administrative practices may be developed
and critically evaluated.

Vincent Ostrom in his book entitled The Intellectual Crisis in American Public Administration (1973) moreover suggested a "democratic administration" (Otenyo 2006: 2) paradigm urging the need for "diverse democratic decision-making structures, popular participation in administration and dispersed administrative authority based upon structures overlapping jurisdiction and fragmented organisation" (Nasrullah 2005: 201).

Thus a paradigm is something the scientists of a discipline agree upon and that guides their research. A mature science is characterised by its paradigm and as long as the so called normal science continues, researchers work within their paradigm to solve the riddles of their discipline. According to Kuhn when the researchers find facts that don't fit into their paradigm and which cannot be explained by it he labels these facts 'anomalies'; he explains that in such situations, researchers begin to search for solutions outside their paradigm until new laws, definitions, orientation hypotheses, values and exemplary solutions are found which can then be used to explain the anomaly and have the power to convince fellow scientists. If this happens and the scholars in that branch of science agree on the new disciplinary system, a new paradigm is installed to serve as a research guide. Under such circumstances a paradigm change (or shift) has occurred (Gruening 1998: 26). If a paradigm has been established within the social sciences and constant research proves that the results cannot be explained or

2. The full form of the abbreviations used in the text are as follows: POSDCORB: Planning, Organising, Staffing, Directing, Coordinating, Reporting, Budgeting. POLC: Planning, Organising, Leading, Controlling. PAFHRIER: Policy Analysis, Financial Management, Human Resource Management, Information Management, External Relations. 
analysed in terms of the accepted paradigm, certain 'anomalies' arise. If the number of anomalies continues to increase and they remain unexplained, the old paradigm is replaced by a new one. Usually when a new paradigm is discovered, all scientific efforts are directed towards the development of that paradigm (Botes 1988: 121).

\title{
New Public Management (NPM) in Africa
}

NPM represents a "paradigmatic break from the traditional model of public administration" (O'Flynn 2007: 353). It is a reformed public sector transformation that breaks away from the repressive, autocratic and conservative paradigm of public administration that followed topdown hierarchies "underpinned by Weber's (1946) bureaucracy, Wilson's (1887) policyadministration divide, and Taylor's (1911) scientific management model of work organisation" (O'Flynn 2007: 354). The components of the NPM as a new paradigm include:

\begin{abstract}
break up of centralised bureaucracy; wide personnel management; shift to desegregations of units in the public sector, involving breaking up of former monolithic units; unbundling public sector into corporative units organised by products; with developed budgets and dealing with one another at 'arms length' basis; shift to greater competition in the public sector through term contracts and public tendering procedures; stress on private sector-styles of management practice - involving a move away military style public service ethic to more flexible hiring, rewards and more use of public relations (Nasrullah 2005: 202-203).
\end{abstract}

NPM is thus seen as a body of managerial thought (Ferlie et al 1996: 9; Larbi 1999: 12) or as an ideological thought system based on ideas generated in the private sector and imported into the public sector (Hood 1991: 3-19, Hood 1995: 104-117; Larbi 1999: 12; Androniceanu 2007: 1).

Most African countries have experienced (some still do) the crisis of political turmoil, intolerance and harsh dictatorship; others have a military regime with highly centralised government processes. To name a few, Sudan, Zimbabwe, Libya, Ethiopia and Uganda are in dire straits, resulting in a marked degree of social disintegration and economic stress throughout the continent. In this scenario of authoritarian ideology, public administration merely administers commandments and decrees. There is a need for African governments to transform these dictatorships, "to incorporate development administration, Africanisation, nation building, and managing change" (Otenyo 2006: 2). Furthermore, economic crises often go hand in hand with political instability; in countries such as Ghana, Malawi, Zambia and Zimbabwe, "the orientation of the political leadership was not particularly pro-market or pro-private sector" (Larbi 1999: 9). In such countries it was therefore necessary to introduce structural adjustment programmes to improve the economic situation prior to public sector management reform. The "structural adjustment reforms initiated in the mid-1980s with the support and leadership of the Bretton Woods institutions introduced a new public administration paradigm and macroeconomic policy framework" (Economic Commission for Africa [ECA] 2004: 4) to advance public sector reform. In other words, such public sector reforms were

initiated against the background that governments required a departure from the traditional methods of administration and the urgent need for a renewed public sector to propel government in its quest for sustainable socio-economic, political and technological development. So, there was a need for structural re-engineering of the public sector with 
the infusion of new values of professionalism, accountability, responsiveness and a focused sense of mission for maximum efficiency in the economy (Omoyefa 2008: 18).

The main objectives of public sector reform were therefore "to achieve better delivery of the basic public services that affect living standards of the poor" (Omoyefa 2008: 18), and "to make the state or government institutional apparatus market friendly, lean, managerial, decentralized and 'customer' friendly...[.]” (Omoyefa 2008: 18). These components of NPM emerged because "many African countries such as Ethiopia, Ghana, Mauritius, Senegal and Uganda, have embarked on comprehensive reforms aimed at improving the quality of life of their citizens, and creating new government machineries to establish efficient and effective management systems" (ECA 2004:1). The NPM approach is seen as a new paradigm to promote the principles of decentralised, democratic and free-market orientated government. This new paradigm implies that traditional Public Administration was not democratic and free-market orientated and failed to improve the institutional, administrative, organisational and structural contexts in Africa. In order to address these challenges, some African countries have adopted the NPM approach. The common elements of NPM as practised in African countries include:

- Decentralisation or decentralising management involves disaggregating and downsizing of public services and are strands of NPM derived from "managerialism" (Mellon 1993: 25-31; Hood 1991: 3-19; Larbi 1999: 17). Examples include Ethiopia (see Gudina 2007: 81-106; Urban Institute 2010: 1); Mali (see Togola \& Gerber 2007: 1-9; Betke 2011: 1); and Senegal (see Rondinelli \& Minis 1990: 447-466). Decentralisation also includes deconcentration, that is, "the passing down of selected administrative functions to lower levels or sub-national units within government agencies or departments" (Hope 2001: 124). Examples include district and town/city councils; land boards; and tribal administration and district administration bodies in Gaborone Botswana (see Lekorwe 1998: 1-16). Another form of decentralisation is delegation. Through delegation, "central governments transfer responsibility for decision making and administration of public functions to semi-autonomous organizations not wholly controlled by the central government, but ultimately accountable to it" (Word Bank 2011: 01). Examples include public corporations in Kenya; parastatals in Lesotho; autonomous hospitals in Botswana and Ghana. Devolution is another type of decentralisation, whereby "the transfer of governance responsibility for specified functions to sub-national levels, either publicly or privately owned, are largely outside the direct control of the central government" (Ferguson \& Chandrasekharan in Yuliani 2004: 3). Examples include the Public Financial Management Programme in Ghana (see Larbi 1999: 19). Another emerging form of decentralisation is privatisation which implies the "transfer of operational control and responsibilities for state functions and service provision to appropriate private sector enterprises or voluntary organisations. From a wider perspective, privatisation encompasses a wide range of policies to encourage private sector participation in public service provision and eliminate or modify the monopoly status of public enterprises" (Hope 2001: 125). Examples here include Togo (see World Bank 2011: 1); New Guinea (see Curtin 2011:1-2); Angola, Botswana, Ghana, Kenya, Mozambique, South Africa, Tanzania, Uganda, Zambia, Camoroon, Cote d'Ivoire, Gabon, Senegal, Guinea, Mali, Rwanda and Sierra Leone (see Hope 2001: 126-127). Parastatals in other African countries are also opting for privatisation programmes in sectors like telecommunication, water, and transport. 
- Contracting out is an alternative term for 'outsourcing' which means "contracting, subcontracting, or 'externalizing' non-core activities to free up cash, personnel, time and facilities for activities" (BusinessDirectory.com 2010: 1) where the state holds economic benefits. Examples include clinical services in Zimbabwe (see McPake \& Hongoro 1995:1), and health services in Liberia (see Gwenigale 2009: 9). The noncore state activities in Uganda (see Olum 2011: 1-20), and Tanzania (see Massi 2011: 1-7) are contracted out.

- Performance contracting: This is an instrument to reform state-owned enterprises. A performance contract is defined as a written or negotiated agreement between government or its representative agency and the management of public enterprises and other autonomous units directly delivering public services. It can also be a contract between government and private managers of state assets, wherein quantifiable targets are explicitly specified for a given period and performance is measured against targets at the end of the period (Larbi 1999: 23). In Kenya, for example, according to information in Nairobi Star of 2 March 2011, the government has embarked upon training 2500 civil servants to work under performance contracts (see Ndanyi 2011:1). Performance-based contracting in Uganda, Democratic Republic of Congo and Rwanda is an outcome-based approach to improving health service delivery (see Johannes et al. 2011: 1).

- Corporatisation: is an emerging trend that involves "converting civil service departments into free-standing agencies or enterprises, either as part of the civil service or completely outside of it. This is perhaps the best known element of civil service reform in the UK and New Zealand, two pioneers of the new public management" (Polidano 1999: 6). Many African countries (Ghana, South Africa and Tanzania for example) are experimenting with the UK and New Zealand models of agencies and enterprises. One particular example of a successful African trend is the combining of "customs and income tax departments into corporatised national revenue authorities. Corporatisation has allowed these bodies to raise wages, shed poor performers while hiring better-qualified staff, offer bonuses in return for meeting revenue targets, and operate on a self-financing basis" (Polidano 1999: 7). This is an African variant of NPM which has been adopted in Ghana, Kenya, Malawi, Tanzania, Uganda and Rwanda (Polidano 1999: 7), followed by Zambia, South Africa and Zimbabwe "who are in a process of corporatising their health sectors" (Russell et al. 1999: 767-75) with high scope of management autonomy, selfsufficiency and self-reliance.

Some of the new techniques under NPM include performance management systems in Botswana (see Dzimbiri 2008: 43-58; Bashi 2008: 1-240); South Africa (see South African Presidency 2007: 1-14); and Uganda (see Hotchkiss et al. 2010: 10-188; O'Neil \& Paydos 2008: 6-11). In addition, NPM reform is evident in pay and grading systems introduced in Ghana, Mozambique, Guinea and Tanzania (see Clarke and Wood 2001: 70-89; Hope 2001: 129); operational and management control systems in South Africa, Ghana, Nigeria, Mauritius (see Hope 2001: 131); total quality management in sub-Saharan African countries (see Mersha 2000: 119-124; Beugré and Offodile 2001: 535-550); and information and communication technologies in service delivery in many African countries (see Miniwatts Marketing Group 2010: 1).

Public sector reform in Africa "awakens the consciousness of people to how responsible governance can be achieved" (Omoyefa 2008: 29). This realisation has enhanced public 
participation with improved people/government communication for good governance. There is also a wider need on the continent to "exploit indigenous knowledge in carrying out any required reform in the public sector. It has always been a case of the donor agencies relying on their own foreign technical expertise and public management wizardry in implementing reform agenda in the African public sector" (Omoyefa (2008: 28).

Analysis of the practical shift of PA to NPM in Africa has raised additional questions for further debate. Is public sector reform the absolute answer to resolve challenges in Africa? Does the NPM paradigm shift have any cultural foundation based on the beliefs and values of the African people per se? Is NPM in Africa a pressure imposed by the developed countries who offer financial aid? Does NPM have the capacity to transform the authoritative administration imposed by African dictatorial headship into a democratised executive and management system that is a participatory and representative system? And one might also ask: Is NPM the only answer to improve and modernise public services in Africa?

The social, economic, political and technological challenges in African countries does not require the prohibition, exclusion or outlawing of public services. "Re-engineering" (ECA 2004: 9) of the public sector is required "with a variety of NPM-inspired measures" (ECA 2004: 9) to enhance the performance and standards of services delivered to the end-users. A literature review of African public administration shows clearly that most countries on the continent still need to "explore frameworks that might explain and sharpen understanding of efforts at reforming public bureaus. Calls for NPM and other reform movements aimed at changing administrative practices and thinking are evidence of the continuation of the search for working systems" (Otenyo 2006: 11).

Various reforms have failed in Africa and it is true to say that

the current global economic crisis, which has considerably discredited the paradigm in
which the reforms are predicted, calls for a new paradigm and a new approach to public
sector reforms. The work of Mhone laid an important foundation for a re-think of
public sector reforms and a re-tooling of the state in Africa ... developmentalism bas to
be the grand normative of any public sector reform agenda in the continent, and it
requires a developmental state, which has to promote both procedural and substantive
democracy (Edigheji 2008: 12-13).

Such an approach to public sector reform will reinforce the "paradigm shift in development thinking evidenced by the adoption of the Millennium Development Goals (MDGs)" (Edigheji 2008: 5). However, further research is required to analyse the role of the New Partnership for Africa's Development (NEPAD) and the African Union (AU) in order to address the developmental challenges that are outlined in the MDGs for the African continent.

\section{The way forward}

At a contextual level, the following paradigm shifts from NPA to NPM must be pursued to improve the public administration challenges on the African continent:

\section{A paradigmatic shift towards market-based reform}

The African continent is struggling with poverty, underdevelopment, and unemployment, all of which are complemented by economic meltdown. The continent is in dire need of regional integration and cooperation to bring market-based reforms. Lack of financial and human 
resources have worsened the situation to the extent that local entrepreneurship and ownership are barely able to survive. To support "regional integration, the Regional Economic Communities (RECs) of Africa - UEMOA and Economic Community of West African States (ECOWAS), Economic Commission for Africa (ECA), Southern Africa Development Community (SADC), and the Common Market for Eastern and Southern Africa (COMESA), are working in partnership" (Vyas-Doorgapersad 2010: 42) to ensure economic strengthening of the continent. This economic development is possible through market-based reforms, and the establishment of micro, small and medium enterprises (both are NPM approaches) that support a paradigm shift in African economic development.

The countries with post-liberalisation problems (for example Madagascar) need to introduce market-based reforms. There are a number of international agencies that are assisting Madagascar to implement financial management for effective use of external aid. These include the Public Financial Accountability Programme (PFA) by the World Bank's Development Grant Facilities (DGF); the European Commission (EC); the UK's Department of International Development (DFID); the Swiss State Secretariat for Economic Affairs (SECO); the Royal Norwegian Ministry of Foreign Affairs; the French Ministry of Foreign Affairs; the International Monetary Fund (IMF); and the Strategic Partnership for Africa (SPA). Moreover the International Development Association-International Finance Corporation (IDA-IFC) is assisting Madagascar to design a micro, small and medium enterprise (MSME) programme for effective utilisation of domestic resources (see World Bank 2010: 1).

\section{A paradigmatic shift towards social reform}

Many African states are 'home' to dictators governed by military regimes (Ethiopia, Uganda, Sudan, Libya, Egypt and Zimbabwe, to name but a few). Social reforms are required to bring democracy so that the people can enjoy basic human rights. Some African countries (for example Libya and Egypt) are suffering mass oppression and are struggling against dictatorships in the quest for freedom of information, speech and expression and improved governance. Post-colonial social reform has resulted in a society that can make claim to basic human rights. Examples of African documents stipulating that all are entitled to enjoy such rights include the Charter of the Organisation of African Unity (1963); the (South African) Freedom Charter (1955); the South African Constitution (1996); and the Arusha Declaration (1967), etc.

There are also social factors that have given impetus to ground-breaking reform in public administration. These involve the relationship between the people and their governments; and those between delegated and elected officials and electors (Tolofari 2005: 78). Such interaction is evident in many African countries (South Africa for example) whereby channels of communication between the government and the governed are open and transparent for improved accountability. This social factor is concisely expressed by Aucoin and Heintzman (2000: 46) who point out that:

\footnotetext{
all governments must now govern in a context where there are greater demands for accountability for performance on the part of a better educated and less deferential citizenry, more assertive and well-organised interest groups and social movements, and more aggressive and intrusive mass media operating in a bighly competitive information-seeking and processing environment.
} 
The mass media and freedom of expression require communication development. Telecommunications (an NPM approach) is a new development paradigm in government communications. It should be noted that southern Africa has the "largest number of cellular subscribers per 100 population, followed by North Africa and West Africa respectively" (UN MDG Report 2009: 55). In addition, use of the Internet is on the increase in Africa. Telecommunication services are now offered in African countries to educate and create awareness of civic and social issues such as HIV/AIDS, public participation and related issues in order to promote social reforms for sustainable development.

A paradigmatic shift towards digital governance

Digital governance is

another new paradigm shift in the offing and getting slowly distinct from its amorphous shape in the horizon of public administration ... the technological inventions in the ways and means of information and communication has dramatically revolutionized the structure, processes and operations of public administration which are almost ubiquitously adopted or tried to be adopted by the governments of both developed and developing countries. Only a letter ' $E$ ' that means 'Electronic' has brought about a glaring transformation in the horizon of public administration (Islam and Abmed 2007: 29-30).

The increasingly wide use of computers has stirred the development towards an NPM approach for enhanced dissemination of information (Cloete 2002: 8). The African continent is in dire need of this paradigm shift where traditional, tribal and rural communities are geographically scattered and do not have access to information. This situation can hamper the effective public participation required for good governance. African countries need changes in governance in the form of intergovernmental structures, "such as the 'one-stop shops' that seek to unite a range of local government service delivery functions. It also occurs across levels of government, such as linkages between the levels of local, regional and central government" (Santos and Heeks 2003: 1) through ICT mechanisms. In the case of southern African countries, "Mauritius, South Africa, Mozambique, Botswana and Namibia have started putting in place institutional and regulatory frameworks solely dedicated for the advancement of e-government adoption" (Bwalya and Healy 2010: 23), that will be further advanced at the regional level.

There are paradigm shifts in African states to implement NPM and improve bureaucratically stagnant, governmentally inoperative, politically paralysed, technologically immobile, economically frail and socially insentient situations. Although this paper expresses concern that NPM should not be seen as the absolute remedy to all the problems that exist, particularly those in crisis states, it is clear that Africans must

overhaul their administrative systems to make them competitive and democratic. The effort must be constructed by the Africans themselves. The main focus of the government reform must be shifted from the hardware in the public services and the government operations. There is also need to evolve an African public service culture or tradition, which is value-based (Fatile and Adejuwon 2010: 154).

The paper therefore suggests a shift in NPM in the form of a Public Value Management (PVM) paradigm suggested by Moore in 1995, one that is already supported by practitioners and academics in the field of public administration/management (Alford 2002; Bovaird 2004; 
Bozeman 2002; Carmeli and Kemmet 2006; Hartley 2005; Hefetz and Warner 2004; Horner and Hazel 2005; Kelly et al. 2002; Moore 1995; Pinnock 2006; Smith et al. 2004; Stoker 2006; O'Flynn, 2007: 353). Under the PVM paradigm

there is a recognition that, in addition to well functioning markets, successful liberal democracies require strong and effective governments able to guarantee fair treatment, equal opportunities, access to a range of key services, and to act as a steward of a country's interests within and across generations (Ssewakiryanga 2008: 3).

The PVM paradigm is described as being

part of a wider networked governance argues that legitimate democracy and effective management are partners. Politics and management go hand in hand. One must involve many stakeholders to make good decisions and to get a grip on delivery and implementation. The public value paradigm places its faith in a system of dialogue and exchange associated with networked governance. It is through the construction, modification, correction, and adaptability of that system that democracy and management are reconciled and delivered (Stoker 2006: 56).

Examples of the PVM paradigm in Africa include the National Monitoring and Evaluation Strategy of Uganda (see Ssewakiryanga 2008: 2-7); and South Africa's government-wide Monitoring and Evaluation System (see South African Presidency 2007). For the effective implementation of PVM paradigm in Africa,

negotiated dialogues with donors is crucial to achieving better outcomes, strengthening decentralization will help to improve service delivery and implementing policy actions will create trust. Solving the three challenges above will ultimately achieve the three elements of public value - outcomes, services and trust (Ssewakiryanga 2008: 6-7).

\section{Conclusion}

During the late 1960s, intellectual voices were raised

against the growing inability of the discipline to reorient itself to the needs of social change ... emphasised the need for bringing Public Administration closer to politics and political theory. The client oriented, normative and socially conscious public administration suggested by the scholars, is the new public administration. Public choice theorists carried toward the trend emphasising de-bureaucratisation and democratic administration (Nasrullab 2005: 203).

The new public management in view of the recent worldwide disenchantment with the public sector is bound to influence public administration and governance in developing countries in the long run. The challenge for developing countries therefore is to integrate the New Public Management model of change with the indigenous-based measure of change in the public sector. What remains to be seen is how developing nations integrate the positive elements of NPM into their own unique systems and bring about changes in their public sector (Nasrullah 2005: 203). Christensen and Lagried (2002: 1-2) are of the opinion that "in some countries there might be a strong element of diffusion of NPM ideas from outside, whereas in others the reform process might be more a national or local initiatives". While the new public management approach may not be a panacea for the problems of public sector management in crisis states, a careful and selective adaptation of some elements to selected sectors may be beneficial. Implementation needs to be sensitive to operational reality (Larbi 1999: 36). 
The debate raised in this paper may not be new, but does offer an analytical compilation of scholarly ideas, thoughts, and opinions. This intellectual debate may lead to paradigm shifts in the way of thinking, perceiving and implementing NPM approaches in crisis countries to bring transformative reforms required for good governance and sustainable development. The article furthermore opens a debate on questions such as: Are African leaders aware of the political values and social cultures that can bring positive transformation for normative governance? How can African countries sustain and maintain indigenous beliefs as a foundational base required for administrative values so as to avoid maladministration? What lessons have African countries learnt through the NPM-led reforms for better future perspective? What levels of improvement can be expected with the introduction of PVM in African countries? Can PVM bring political reform to ensure that there be stable African governments with democratic rights? Can PVM lead to governance free of social, economic and political corruption in Africa? Is PVM the absolute paradigm to resolve challenges in crisis states or can another paradigm be expected in the near future? These questions leave a scope for further exploration to analyse the implementation of the Public Value Management paradigm on the African continent and ensure good governance in the immediate future and beyond.

\section{References}

Alford, J. 2002. 'Defining the Client in the Public Sector: A Social Exchange Perspective'. Public Administration Review, 62 (3): 337-346.

Androniceanu, A. 2007. 'New Public Management, a Key Paradigm for Reforming Public Management in Romanian Administration'. Administratie Si Management Public, 8: 154-161.

Aucoin, P. and R. Heintzman. 2000. 'The Dialectics of Accountability for Performance in Public Management Reform'. International Review of Administrative Sciences, 66 (1): 45-55.

Bashi, M. 2008. Public Sector Reforms and Managing Change in Botswana: The Case of Performance Management System (PMS). (http://drc.ohiolink.edu/handle/2374.OX/104983). Accessed on 19 July 2010.

Beugre, C.D. and O.F. Offodile. 2001. 'Managing for Organizational Effectiveness in SubSaharan Africa: A Culture-fit Model'. The International Journal of Human Resource Management, 12 (4): 535-550.

Betke, D. 2011. Promotion of Local Governance in Mali. (http://www.gtz.de/en/weltweit/afrika/mali/19602.htm). Accessed on 19 September 2011.

Botes, P.S. 1988. 'Public Administration: Paradigmatic Status', in JSH Gildenhuys (ed.), South African Public Administration: Past, Present and Future. Pinetown: Owen Burgess Publishers, pp. 119-130. 
Bovaird, T. 2004. 'Public-Private Partnerships: From Contested Concepts to Prevalent Practices'. International Review of Administrative Sciences, 70, (2): 199-215.

Bozeman, B. 2002. 'Public-Value Failure: When Efficient Markets May Not Do'. Public Administration Review, 62 (2): 145-161.

BusinessDictionary.com.2010. Contracting out. (http://www.businessdictionary. com/definition/outsourcing.html). Accessed on 25 August 2010.

Bwalya K. J. and M. Healy. 2010. 'Harnessing e-Government Adoption in the SADC Region: a Conceptual Underpinning'. Electronic Journal of e-Government, 8 (1): 23-32.

Carmeli, A. and L. Kemmet. 2006. 'Exploring Fit in Public Sector Organizations'. Public Money and Management, 26 (1): 73-80.

Charih, M. and L. Rouillard. 1997. 'The New Public Management', in M. Chariah and D. Arthur (eds.), New Public Management and Public Administration in Canada. Toronto: Institute of Public Administration of Canada, pp. 27-45.

Cheung, A. B. L. 1997. 'Understanding Public Sector Reforms: Global Trends and Diverse Agendas'. International Review of Administrative Sciences, 63 (4): 435-57.

Chevallier, J. and D. Loschak (eds). 1978. Traite de science administrative. Part I. Theorie generale de linstitution administrative. Paris: Librairie generale de droit et de jurisprudence.

Christensen, T. and P. Lægreid. 2002. 'A Transformative Perspective on Administrative Reforms', in T. Christensen and P. Lægreid (eds.), New Public Management: The Transformation of Ideas and Practice. UK: Ashgate, pp.13-42.

Clarke, J. \& D. Wood. 2001. 'New Public Management and Development: The Case of Public Service Reform in Tanzania and Uganda', in W. McCourt and M. Minogue (eds), The Internationalization of Public Management: Reinventing the Third World State. UK: Edward Elgar, pp. 70-89.

Cloete, F. 2002. Building Public Sector Capacity in Developing Societies with Electronic Management Support Tools. (http://www.sopmp.sun.ac.za/faniecloete/Papers/istanbul.doc).

Curtin, T. 2011. Privatization Policy in Papua New Guinea. (http://epress.anu.edu.au/ssgm/policy_making/mobile_devices/ch18.html). Accessed on 17 June 2011.

Dzimbiri, L.B. 2008. 'Experiences in New Public Management in Africa: The Case of Performance Management Systems in Botswana'. Africa Development, XXXIII (4): 43-58.

Economic Commission for Africa. 2004. Public Sector Management Reforms in Africa. Ethiopia: ECA.

Edigheji, O. 2008. 'Public Sector Reforms and the Quest for Democratric Developmentalism in Africa'. Africa Development, Vol.XXXIII (4): 1-13.

Fatile, J.O. and K.D. Adejuwon. 2010. 'Public Sector Reform in Africa: Issues, Lessons and Future Directions'. Journal of Sustainable Development in Africa, 12 (8): 145-157. 
Ferlie, E., A. Pettigrew, L. Ashburner and L. Fitzgerald (eds). 1996. The New Public Management in Action. Oxford: Oxford University Press.

Frederickson, G. 1980. New Public Administration. Tuscaloosa: University of Alabama Press.

Freysen, C. 1988. 'Public Administration: Paradigmatic Status', in J.S.H. Gildenhuys (ed.), South African Public Administration: Past, Present and Future. Pinetown: Owen Burgess Publishers, pp. 159-167.

Gow, J.L. and C. Dufour. 2000. 'Is the New Public Management a Paradigm? Does it matter?'. International Review of Administrative Sciences, 66 (4): 573-597.

Gruening, G. 1998. Origin and Theoretical Basis of the New Public Management (NPM). (www.inpuma.net/research/papers/salem/gernod.doc). Accessed on 17 March 2010.

Gudina, M. 2007. 'Ethnicity, Democratisation and Decentralization in Ethiopia: The Case of Oromia'. Eastern Africa Social Science Research Review, 23 (1): 81-106.

Gwenigale, W.T. 2009. Contracting Out Core Government Functions and Services in Fragile and Post-Conflict Situations. (http://www.oecd.org/dataoecd/33/18/43950044.pdf). Accessed on 21 April 2011.

Harmon, M.M. 1981. Action Theory for Public Administration. Burke, VA: Chatelaine Press.

Hartley, J. 2005. 'Innovation in Governance and Public Services: Past and Present'. Public Money and Management, 25 (1): 27-34.

Hefez, A. and M. Warner. 2004. 'Privatization and its Reverse: Explaining the Dynamics of the Government Contracting Process'. Journal of Public Administration Research and Theory, 14 (2): 171-190.

Henry, N. 1975. 'Paradigms of Public Administration'. Public Administration Review, 35 (4): 378-85.

Hood, C. 1991. 'A Public Management for All SAeasons'. Public Administration, 69 (1): 319.

Hood, C. 1995. 'Contemporary Public Management: A New Global Paradigm'. Public Policy and Administration, 10 (2): 104-117.

Hope, K.R. 2001. 'The New Public Management: Context and Practice in Africa'. International Public Management Journal, 4: 119-134.

Horner, L. and L. Hazel (eds). 2005. Adding Public Value. London: The Work Foundation.

Hotchkiss, D.R., A. Aqil, T. Lippeveld, and E. Mukooyo. 2010. Evaluation of the Performance of Routine Information System Management (PRISM) framerwork: evidence from Uganda. (http:// 3. doi: 10.1186/1472-6963-10-188. PMCID: PMC2904760 10: 188).

Islam, M.M. and A.M.S. Ahmed. 2007. 'Understanding E-Governance: A Theoretical Approach'. Asian Affairs, 29 (4): 29-46

Johannes, L., P. Mullen, P. Okwero, and M. Schneidman, M. 2011. Performance-based Contracting in Health: The Experience of Three Projects in Africa. (http:// www.gpoba.org/gpoba/node/115). Accessed on 23 August 2011. 
Kaboolian, L. 1998. 'The New Public Management: Challenging the Boundaries of the Management vs. Administration Debate'. Public Administration Review, 58 (3): 189193.

Kelly, G., G.H. Mulgan, and S. Muers (eds). 2002. Creating Public Value: An Analytical Framework for Public Service Reform. UK: Cabinet Office Strategy Unit.

Kuhn, T.S. 1970. The Structure of Scientific Revolutions. Chicago: University of Chicago Press.

Lan, Z. and K.K. Anders. 2000. 'A Paradigmatic View of Contemporary Public Administration Research: An Empirical Test'. Administration E' Society, 32 (2): 138165.

Larbi, G.A. 1999. The New Public Management Approach and Crisis State. Geneva: United Nations Research Institute for Social Development.

Lekorwe, M. 1998. 'The Politics of Urban Governance and Management in Gaborone'. Botswana Journal of African Studies, 12 (1 \& 2): 69-84.

Maserumule, M.H. and P. Mashigo, 2011. 'Public Administration and Economics: TwinSciences That [Should] Go Together for Rounded-Knowledge?' (http://www.aabri.com/manuscripts/09210.pdf). Accessed on 23 July 2011.

Massey, A. 1997. Globalization and Marketization of Government Services. London: Macmillan.

Massi, M.M.Z. 2011. Private Sector Participation in Morogoro Regional Hospital United Republic of Tanzania President's Office. (http://www.districthealthservice. com/cms/upload/innolink_6_7160.doc). Accessed on 16 July 2011.

McPake, B. and C. Hongoro, 1995. Contracting out of Clinical Services in Zimbabwe. (http://www.ncbi.nlm.nih.gov/pubmed/7667666). Accessed on 05 March 2010.

Mellon, E. 1993. 'Executive Agencies: Leading Change from the Outside'. Public Money and Management, 13 (2): 25-31.

Mersha, T. 2000. Quality, Competitiveness and Development in Sub-Saharan Africa. (http://www.emeraldinsight.com/journals.htm?articleid=849978\&show=html). Accessed on 07 March 2010.

Miniwatts Marketing Group, 2010. Internet Usage Statistics for Africa: Africa Internet Usage and Population Stats. (http://www.internetworldstats.com/stats1.htm). Accessed on 18 July 2011.

Minogue, M. 1983. 'Theory and Practice in Public Policy and Administration'. Policy and Politics, 11 (1): 63-85.

Moore, M. 1995. Creating Public Value: Strategic Management in Government. Cambridge MA: Harvard University Press.

Nasrullah, A.M. 2005. 'From Public Administration to New Public Management: An Analysis'. Pakistan Journal of Social Sciences, 3 (1): 197-204.

Ndanyi, M. 2011. Kenya: 2,500 Civil Servants Trained on Performance Contracts. (http://allafrica.com/stories/201103030569.html). Accessed on 20 July 2011. 
Olum, Y. 2011. Public Service Reform in Uganda (1989-2002): A Critical Appraisal. (http://unpan1.un.org/intradoc/groups/public/documents/AAPAM/UNPAN025827.pd f). Accessed on 26 August 2011.

O’Flynn, J. 2007. 'From New Public Management to Public Value: Paradigmatic Change and Managerial Implications'. The Australian Journal of Public Administration, 66 (3): 353-366.

Omoyefa, P.S. 2008. 'Public Sector Reforms in Africa: A Philosophical Re-thinking'. Africa Development, XXXIII (4): 15-30.

Online Dictionary of Social Sciences. 2006. Paradigm. http://bitbucket.icaap.org/dict.pl?alpha=P. Accessed on 18 July 2011.

O'Neil, M.L. and M. Paydos. 2008. Improving Retention and Performance in Civil Society in Uganda. (http:// doi: 10.1186/1478-4491-6-11.PMCID: PMC24403766:11).

Ostrom, V. 1973. The Intellectual Crisis in American Public Administration.Alabama: University of Alabama Press.

Otenyo, E.E. 2006. Vincent Ostrom's Democratic Administration and New Public Management in East Africa. (http://www.indiana.edu/ vcoconf/papers/otenyo_voconf.pdf). Accessed on 16 September 2010.

Peters, G. and D. Savoie (ed). 1995. Governance in a Changing Environment. Montreal: McGill-Queen's University Press.

Pinnock, A. 2006. 'Public Value or Intrinsic Value? The Arts-Economic Consequences of Mr Keynes'. Public Money and Management, 26 (3): 173-179.

Polidano, C. 1999. The New Public Management in Developing Countries. University of Manchester: Institute for Development Policy and Management.

Rondinelli, DA and H.P. Minis. 1990. 'Administrative Restructuring for Economic Adjustment: Decentralization Policy in Senegal'. International Review of Administrative Sciences, 56 (3): 447-466.

Russell, S., S. Bennett, and A. Mills. 1999. 'Reforming the Health Sector: Towards a Healthy New Public Management'. Journal of International Development, 11 (5): 767-75.

Santos, R. \& R. Heeks (eds). 2003. ICTs and Intra-Governmental Structures at Local, Regional and Central Levels: Updating Conventional Ideas. University of Manchester: IDPM.

Smith, R.F.I., E. Anderson and J. Teicher. 2004. 'Toward Public Value?'. Australian Journal of Public Administration, 63 (4): 14-15.

Ssewakiryanga, R. 2008. Can Public Sector Management Reforms Create Public Value? Experiences in Setting up a National Monitoring and Evaluation Strategy for Uganda. (http://api.ning.com/files/TNumCALNntfLIYZfvDzj3Aw8pG1 eubIBKD81vGHSoqb Lr9FPTKs5nCv1MoOjzFE8F2hS51JmFjzmyuwapFEbrkSJJFflCu/AfCoP_news_Apri 1 08.pdf). Accessed on 23 July 2010.

Stoker, G. 2006. 'Public Value Management: A New Narrative for Networked

Governance? '. American Review of Public Administration, 36 (1): 41-57.

Terry, L.D. 1998. 'Leadership, Neo-managerialism and the New Public Management Movement'. Public Administration Review, 58 (3): 194-200. 
The Presidency (South Africa). 2007. Policy Framework for the Goverment-wide Monitoring and Evaluation Systems. Pretoria: Government Printer.

Thomas, P. 1996. 'Beyond the Buzzwords: Coping with Challenge in the Public Sector'. International Review of Administrative Sciences, 62 (1): 5-36.

Togola, A. and D. Gerber. 2007. An Evaluation of Malian Civil Society's Role in Governance.

(http://afrimap.org/english/images/paper/Mali_Civil_Society(fin).pdf). Accessed on 24 August 2010.

Tolofari, S. 2005. Policy Futures in Education. (http://firgoa.usc.es/drupal/files/tolofari.pdf). Accessed on 10 September 2010.

UN MDG Report, 2009. Assessing Progress in Africa toward the Millennium Development Goals.

(http://www.afdb.org/fileadmin/uploads/afdb/Documents/Publications/Section\%202. pdf). Accessed on 26 September 2010.

Urban Institute, 2010. Ethiopia: Deepening Decentralization and Local Government Restructuring.

(http://www.urban.org/center/idg/projects/pdescrip.cfm?ProjectID=317). Accessed on 02 November 2010.

Vyas-Doorgapersad, S. 2010. 'The Impact of Global Partnership for Development (Goal Number 8) in Achieving the Millennium Development Goals in Africa'. Africa Insight, 40 (2): 39-53.

Wilding, P. 1992. 'The British Welfare State: Thatcherism's Enduring Legacy'. Policy and Politics, 20: 201-12.

World Bank. 2010. Meeting the Challenge of Africa's Development: A World Bank Group Action Plan. (http://www.sarpn.org.za). Accessed on 17 March 2011.

World Bank. 2011. The Online Sourcebook on Decentralization and Local Development. (http://www.ciesin.org/decentralization/Entryway/SCBKSponsors.html). Accessed on 06 April 2011.

World Bank, 2011. Togo Public Enterprise Restructuring and Privatization Support Project. (http://www.worldbank.org.md/WBSITE/EXTERNAL/COUNTRIES/ECAEXT/ MOLDOVAEXTN/0,,contentMDK:20026458 menuPK:34471 pagePK:34370 pi PK:34424 theSitePK:302251,00.html). Accessed on 18 August 2011.

Yuliani, 2004. Decentralization, Deconcentration and Devolution: What do they Mean? (http://www.cifor.cgiar.org/publications/pdf_files/interlaken/Compilation.pdf). Accessed on 23 August 2011. 